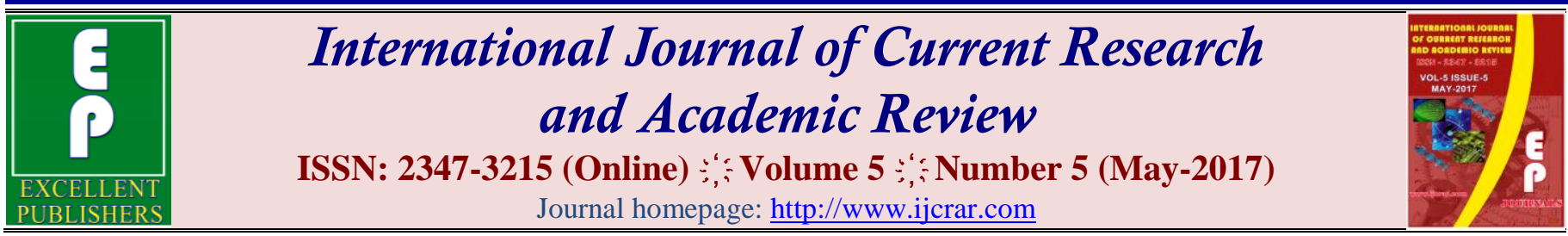

doi: https://doi.org/10.20546/ijcrar.2017.505.009

\title{
Crop Establishment Method and Irrigation Schedule Effect on Water Productivity, Economics and Yield of Wheat (Triticum aestiuvm $\mathbf{L}$ )
}

\author{
Vipin Kumar Sagar ${ }^{1}$, R.K. Naresh ${ }^{1 *}$, Vivak Kumar ${ }^{2}$, Satendra Kumar ${ }^{3}$, Saurabh Tyagi ${ }^{1}$, Vineet \\ Kumar $^{4}$, Sunil Kumar ${ }^{4}$, Nihal Chandra Mahajan', Arun Kumar ${ }^{1}$, Vikrant Singh ${ }^{5}$, \\ S.P. Singh ${ }^{3}$ and R.C. Rathi ${ }^{6}$
}

${ }^{1}$ Department of Agronomy; ${ }^{2}$ Department of Agricultural Engineering; ${ }^{3}$ Department of Soil Science; ${ }^{6}$ K.V.K.Beghra Sardar Vallabhbhai Patel University of Agriculture and Technology, Meerut-250110, U.P., India

${ }^{4}$ Indian Institute of Farming System Research, Modipuram-Meerut-250110, U.P., India

${ }^{5}$ Directorate of Sugarcane Development, Aliganj, Lucknow- 226024 (U.P)

*Corresponding author:

\begin{abstract}
Field study was conducted at Crop Research Centre of Sardar Vallabhbhai Patel University of Agri. \& Tech. Meerut, Uttar Pradesh during 2014-16 in a split plot design having three replications. Six land configuration systems $B_{1}-75 \mathrm{~cm}$ bed, 2 rows $\left(\mathrm{B}_{75-2}\right) ; \mathrm{B}_{2^{-}}, 75 \mathrm{~cm}$ bed, 3 rows $\left(\mathrm{B}_{75-3}\right) ; \mathrm{B}_{3^{-}} 90 \mathrm{~cm}$ bed, 2 rows $\left(\mathrm{B}_{90-2}\right) ; \mathrm{B}_{4^{-}} 90 \mathrm{~cm}$ bed, 3 rows $\left(\mathrm{B}_{90-3}\right), \mathrm{B}_{5^{-}} 90 \mathrm{~cm}$ bed, 4 rows $\left(\mathrm{B}_{90-4}\right) ; \mathrm{B}_{6^{-}}$Flat planting , rows $22.5 \mathrm{~cm}$ apart were laid out in main plots whereas the subplots were three irrigation schedule practices such as $\mathrm{I}_{1^{-}} 4 \mathrm{~cm}$ irrigation at IW/CPE $0.8 ; \mathrm{I}_{2^{-}} 5 \mathrm{~cm}$ irrigation at IW/CPE $1.0 ; \mathrm{I}_{3^{-}} 6 \mathrm{~cm}$ irrigation at IW/CPE 1.2. The objective of the study was to examine the treatment effects on water productivity, yield and profitability of wheat crop. Results showed that the grain yield $\left(46.52 ; 47.63\right.$ and 44.01 and $\left.44.88 \mathrm{q} \mathrm{ha}^{-1}\right)$, straw $(60.57 ; 61.55$ and 59.94; $\left.102.75 \mathrm{q} \mathrm{ha}^{-1}\right)$ biological yield $\left(107.09 ; 109.40\right.$ and $\left.102.75 ; 104.82 \mathrm{q} \mathrm{ha}^{-1}\right)$ and harvest index $(43.39 ; 43.49$ and $42.53 ; 42.77)$ were significantly higher in $\mathrm{B}_{90-4}$ and 4 $\mathrm{cm}$ irrigation at IW/CPE 0.8 during both the year of study. Physiological traits, yield attributes and yields were significantly influenced by land configuration and irrigation practices. In land configuration systems, $\mathrm{B}_{90-4}$ and $4 \mathrm{~cm}$ irrigation at IW/CPE 1.2 displayed significantly higher water use efficiency $\left(2.53 ; 2.51\right.$ and $\left.2.19 ; 2.18 \mathrm{~kg} \mathrm{~m}^{-3}\right)$ compared with other treatments. However irrigation schedules $\times$ land configuration interaction was significant for yield attributes grain, straw and biological yield. The higher net return of Rs. 57805 and Rs. $61363 \mathrm{ha}^{-1}$ and B: C ratio 2.08 and 2.14 registered in $\mathrm{B}_{90-4}$ treatment. As well as irrigation schedule with IW/CPE $0.8\left(\mathrm{I}_{1}\right)$ recorded more net return Rs.53762 and Rs. $57059 \mathrm{ha}^{-1}$ and B: C ratio 1.89 and 1.94 than other treatments. The crop planted on $90 \mathrm{~cm}$ beds with 4 rows on the top of the bed and IW/CPE 0.8 is important in the Typic Ustochrept soil to achieve sustainable increase in wheat production to meet future demand while conserving natural resources, especially irrigation water and reducing the negative effects on the environment.
\end{abstract}

\section{Article Info}

Accepted: 05 May 2017

Available Online: 20 May 2017

\section{Keywords}

Land configuration, irrigation schedule, IW/CPE, water productivity. 


\section{Introduction}

Wheat a major cereal crop is being cultivated in the country. The main reasons for its productivity are poor crop establishment and improper scheduling of irrigation. Amongst the other agronomic practices proper crop establishment method may considerably increase the production of wheat up to some extent. Ideal planting geometry is important for better and efficient utilization of plant growth resources get the optimum productivity of wheat. It is also well know fact that water management is one of the major factors responsible for achieving better harvest in crop production. Both crop establishment method and irrigation schedule are major causes of yield reduction in wheat, which also affect its water use efficiency. Farmers are always interested in getting higher yield which could not be possible without better crop management, good stand establishment and optimum utilization of resources. Crop production is influenced by its establishment and plant vigour representing the key factors towards crop development (Amanullah et al., 2009).

Raised beds are formed by moving soil from the furrows to the area of the bed, thus raising its surface level. The furrows serve as irrigation channels, drains and traffic lanes. Generally, two to six rows is planted on the top of each bed for rice crop (Naresh et al, 2011; Saharawat et al., 2010). In raised bed technique, the bed furrow system once developed is not destroyed seasons after seasons. The beds are only renovated and not misplaced. The renovation operation consists of only using a bed renovator. The bed renovator consists of two or three furrowers depending on the size of the raised beds for cleaning the furrows and two horizontal blades that cuts the bed at the base of crop root zone without disturbing the top of the bed. As experience has been gained with bed planting and appropriate implements have been developed, farmers who grow crops on beds can now simply reshape the beds before planting the next crop and retain all or part of the crop residues on the surface, a practice referred to as 'Permanent Raised Bed Planting'.

Raised bed dimensions and configurations vary with soil type and available machinery. The ability of the soil to 'sub' (i.e. allow the lateral movement of irrigation water into the centre of the bed) is a key determinant of bed dimensions. For sandy loam soils that sub easily, growers use bed widths at $1.37 \mathrm{~m}$ centres for all crop types like rice, wheat. Soils do not sub as well; narrower beds at $0.67 \mathrm{~m}$ centres are frequently used. Bed height may also vary with soil conditions and field slope.
Higher beds are frequently used on soils that sub well and have flatter grades and longer run lengths, while beds of a lower height are used on steeper graded fields. The flat top of the bed varies from 0.37 to $1.07 \mathrm{~m}$ in width. Furrow irrigation used with raised beds requires growers to adopt a whole-farm planning approach to deal with drainage water and the integration of on farm drains and drainage water recycling systems, to increase both water use efficiency and drainage water quality control (Beecher et al, 2005).

It is also well know fact that water management is one of the major factors responsible for achieving better harvest in crop production. Proper scheduling of irrigation (amount and timing) to crops is an important component of water saving technologies. There are numerous ways to schedule irrigations and estimate the required depth of water application (Campbell and Campbell 1982; Prihar et al. 1997). All irrigation scheduling methods consist of monitoring indicators that determine the need for irrigation. Prihar et al., (1974) suggested a simple approach based on meteorological parameters to schedule irrigation to crops based on the ratio between fixed depth $(75 \mathrm{~mm})$ of irrigation water (IW) and net cumulative pan evaporation since previous irrigation (PAN-E minus rainfall). Irrigating wheat using this approach (IW/PAN-E $=0.9)$ saves 2 irrigation compared to 5-6 irrigations at fixed growth stages without any yield loss (Prihar and Sandhu, 1987). Being the prime natural resource for assured crop production, water has to be used judiciously and in scientific manner. Both crop establishment method and irrigation schedule are major causes of yield reduction in wheat, which also affect its water productivity and profitability. This paper presents a result of the on-farm experiment and observation from bed/flat sown wheat crop currently practiced in the western Uttar Pradesh, India.

\section{Materials and Methods}

\section{Experimental site}

The field experiment was established in 2014 at Sardar Vallabhbhai Patel University of Agriculture \&Technology, Meerut research farm $\left(29^{\circ} 04^{\prime}, \mathrm{N}\right.$ latitude and $77^{\circ} 42^{\prime}$ ' $E$ longitude a height of $237 \mathrm{~m}$ above mean sea level) U.P., India. The region has a semi-arid subtropical climate with an average annual temperature of $16.8^{\circ} \mathrm{C}$. The highest mean monthly temperature $\left(38.9^{\circ} \mathrm{C}\right)$ was recorded in May, and the lowest mean monthly temperature $\left(4.5^{\circ} \mathrm{C}\right)$ was recorded in January. The average annual rainfall was about 665 to $726 \mathrm{~mm}$ 
(constituting $44 \%$ of pan evaporation) of which about $80 \%$ was received during the monsoon period. The predominant soil at the experimental site was classified as Typic Ustochrept. Soil samples for $0-20 \mathrm{~cm}$ depth at the site were collected and tested prior to applying treatments and the basic properties were non-saline (EC $0.42 \mathrm{dS} \mathrm{m}^{-1}$ ) but mild alkaline in reaction ( $\mathrm{pH}$ 7.98). The soil initially had $4.1 \mathrm{~g} \mathrm{~kg}^{-1}$ of SOC and $1.29 \mathrm{~g} \mathrm{~kg}^{-1}$ of total $\mathrm{N}$ (TN), $1.23 \mathrm{~g} \mathrm{~kg}^{-1}$ of total phosphorus, $17.63 \mathrm{~g} \mathrm{~kg}^{-1}$ of total potassium, $224 \mathrm{mg} \mathrm{kg}^{-1}$ of available $\mathrm{N}, 4.0 \mathrm{mg}$ $\mathrm{kg}^{-1}$ of available phosphorus, and $97 \mathrm{mg} \mathrm{kg}^{-1}$ of available potassium.

\section{Experimental design and management}

A detailed description of crop establishment methods were necessary to compare the influence of land configuration practices on environmental performance (Derpsch et al., 2014).Six crop establishment methods $\mathrm{B}_{1^{-}} 75 \mathrm{~cm}$ bed, 2 rows $\left(\mathrm{B}_{75-2}\right) ; \mathrm{B}_{2^{-}}, 75 \mathrm{~cm}$ bed, 3 rows $\left(\mathrm{B}_{75-3}\right) ; \mathrm{B}_{3^{-}} 90 \mathrm{~cm}$ bed, 2 rows $\left(\mathrm{B}_{90-2}\right) ; \mathrm{B}_{4^{-}} 90 \mathrm{~cm}$ bed, 3 rows $\left(\mathrm{B}_{90-3}\right), \mathrm{B}_{5^{-}} 90 \mathrm{~cm}$ bed, 4 rows $\left(\mathrm{B}_{90-4}\right) ; \mathrm{B}_{6^{-}}$Flat planting, rows $22.5 \mathrm{~cm}$ apart in main plots and three irrigation schedule practices were $I_{1}-4 \mathrm{~cm}$ irrigation at IW/CPE 0.8; $\mathrm{I}_{2}-5 \mathrm{~cm}$ irrigation at IW/CPE $1.0 ; \mathrm{I}_{3}-6 \mathrm{~cm}$ irrigation at IW/CPE 1.2 allotted to sub-plots in a splitplot design and replicated thrice. The gross and net plot sizes were $7.0 \mathrm{~m} \times 24.5 \mathrm{~m}$ and $6.0 \mathrm{~m} \times 3.5 \mathrm{~m}$, respectively and treatments were superimposed in the same plot every year to study the cumulative effect of treatments.

\section{Preparation of furrow irrigated raised beds}

At the beginning of the experiment soil was tilled by harrowing and ploughings followed by one field levelling with a wooden plank, and raised beds were made using a tractor-drawn multi crop zero till cum raised bed planter with inclined plate seed metering devices. The dimension of the raised beds were 45 and $60 \mathrm{~cm}$ wide (top of the bed) $\times 18 \mathrm{~cm}$ height $\times 30 \mathrm{~cm}$ furrow width (at top) and the spacing from centre of the furrow to another centre of the furrow was kept at 75 and $90 \mathrm{~cm}$. In furrow irrigated raised bed planting system, the crop was planted on the top of beds in bed configurations of $45 \mathrm{~cm}$ bed and $60 \mathrm{~cm}$ bed.

\section{Preparation of conventional tillage}

After the rice harvest, following the conventional practice of two harrowing, two ploughing (using a cultivator) and one planking (using a wooden plank) that followed pre-sowing irrigation and wheat was seeded in flat planting, a uniform row-to-row distance of $22.5 \mathrm{~cm}$ was maintained. Using a seed drill with a dry-fertilizer attachment.

\section{Nutrient application}

Plant nutrients were applied as per the state recommendations for wheat $\left(\mathrm{N}_{120}+\mathrm{P}_{60}+\mathrm{K}_{40}\right)$. Urea, diammonium phosphate and muriatic of potash, were placed in band in seed rows at the time of sowing using zero till cum raised beds planter with inclined plate metering device. The remaining $\mathrm{N}$ was broadcasted with dry urea in two equal splits of $30 \mathrm{~kg} \mathrm{~N} \mathrm{ha}^{-1},\left(\mathrm{~N}_{30}\right)$ at crown root initiation (CRI) and the flag leaf initiation (FLI) crop growth stages.

\section{Sowing techniques}

Wheat cultivar DBW-17 was shown on November 2015 and 2016 using $80 \mathrm{~kg} \mathrm{ha}^{-1}$ for raised beds and $100 \mathrm{~kg}$ seed $\mathrm{ha}^{-1}$ for flat planting were done using zero till cum raised beds planter with inclined plate metering device.

\section{Weed management}

The crop was maintained with weed free using following practices. Weeds were controlled by spraying of herbicide Sulfosulfuron + Metsulfuron (Total) @ $35 \mathrm{~g}$ a.i. ha ${ }^{-1}$ and applied uniformly in standing crop to control the weeds at 30-45 DAS. To check the weed growth, one inter culture operation was done during the study after eight week sown crop with the help of manual weeding.

\section{Irrigation scheduling}

Measured quantity of irrigation water was applied to the plots as per the irrigation schedule. For measuring irrigation water, volume method was used. Irrigations were scheduled on IW: CPE ratio in individual treatments. The source of irrigation water was Tube well with good quality water for irrigation.

\section{Water application and measurements}

Irrigation water was applied using polyvinyl chloride pipes of 15-cm diameter and the amount of water applied to each plot was measured using a water meter (Dasmesh Co., India). The quantity of water applied and the depth of irrigation was computed using the following equations: 
Quantity of water applied $(L)=F \times t$ (1)

Depth of water applied $(\mathrm{cm})=L / A / 1000$ (2)

Where $F$ is flow rate (L/s), $t$ is time (s) taken during each irrigation and $A$ is area of the plot $\left(\mathrm{m}^{2}\right)$. Rainfall data was recorded using a rain gauge installed within the meteorological station. The total amount of water (input water) applied was computed as the sum of water received through irrigation (I) and rainfall (R).Water productivity $\left(W P_{\mathrm{I}+\mathrm{R}}\right)\left(\mathrm{kg} / \mathrm{m}^{3}\right)$ was computed as follows (Humphreys et al, 2008)

$W P_{\mathrm{I}+\mathrm{R}}=$ Grain yield/ (Irrigation water applied (I) + Rainfall received by the crop (R)).

(3)

\section{Water use studies}

Soil moisture content was measure at seeding, and before and after each irrigation on the top of the ridge and furrow in furrow irrigated raised bed planting system and between the 2 rows in flat planting by using neutron moisture meter. Water saving (WS) was calculated as:

$\mathrm{WS}=\left(\mathrm{Q}_{\mathrm{F}}-\mathrm{Q}_{\mathrm{B}}\right) / \mathrm{Q}_{\mathrm{F}} \times 100$,

Where $\mathrm{Q}_{\mathrm{F}}$ and $\mathrm{Q}_{\mathrm{B}}$ are quantity of water applied in flat planting and furrow irrigated raised bed planting system, respectively. The soil moisture data would be utilized to calculate the consumptive use.

\section{Results and Discussion}

\section{Yield attributes}

Data on various yields attributing characters viz. spike length, number of spikelet's spike ${ }^{-1}$, number of grains spike $^{-1}$, and test weight, as influenced by crop establishment method and irrigation schedule are presented in (Table 1) found that $\mathrm{B}_{75-2}$ land configuration significantly higher spike length over other treatments. The number of spikelet's spike ${ }^{-1}$, number of grains spike ${ }^{-1}$, and test weight were higher with land configuration $\mathrm{B}_{90-2}$ as compare to remaining treatments during the year of study. The number of grains spike ${ }^{-1}$ was higher under 90 $\mathrm{cm}$ followed by than $75 \mathrm{~cm}$ raised beds and lower under flat beds. The irrigation scheduled of $4 \mathrm{~cm}$ at IW/CPE 0.8 were recorded significantly more values for all the above yield attributes as compare to other irrigation treatments during the year of study. However, stimulated vegetative growth of wheat on account of adequate and prolonged supply of water in treatment manifested itself by increased spike length, number of spikelet's spike ${ }^{-1}$, number of grains spike ${ }^{-1}$, and test weight. These results are consistent with previous studies Jat and Singh 2003; Maurya and Singh 2008.

\section{Yield}

The grain $\left(46.52,47.63 \mathrm{q} \mathrm{ha}^{-1}\right)$, straw $\left(60.57,61.55 \mathrm{q} \mathrm{ha}^{-1}\right)$, biological 107, $109.40 \mathrm{q} \mathrm{ha}^{-1}$ ) yields and harvest index (43.39 and 43.49) were recorded significantly higher (Table 2) with land configuration $\mathrm{B}_{90-4}$ as compared to all other treatments during experimentation. The grain yield increased 11.00 and $12.02 \%$, straw yield 7.0 and $7.3 \%$ with land configuration $\mathrm{B}_{90-4}$ over flat planting during first and second year, respectively. Treatments $\mathrm{B}_{75-4}\left(\mathrm{~B}_{2}\right)$ and flat planting $\left(\mathrm{B}_{6}\right)$ were at par with each other during both the year of study. However, $\mathrm{B}_{90-2}\left(\mathrm{~B}_{3}\right)$ was recorded the lowest grain yield during both the year of study. Higher grain yield with bed planting of wheat has been also reported by (Bhahma et al. 2007; Kumar 2010; Thind et al. 2010).

The results have clearly shown that the grain yield in land configurations $\mathrm{B}_{75-2}, \mathrm{~B}_{75-3}, \mathrm{~B}_{90-2}$ and $\mathrm{B}_{90-3}$ was lower than that in flat planting due to low plant density, but the yield was higher in $\mathrm{B}_{90-4}$ than flat planting $\left(\mathrm{B}_{5}\right)$. The irrigation schedules having good tillering and higher rates of photosynthesis, had high biomass production and therefore was more suited for furrow irrigated raised bed planting system than flat planting.

Among the irrigation schedules IW/CPE $0.8\left(\mathrm{I}_{1}\right)$ and IW/CPE $1.0\left(\mathrm{I}_{2}\right)$ produced higher number of spikes and biological yield than IW/CPE $1.2\left(\mathrm{I}_{3}\right)$. The significantly higher grain, straw, biological yields and harvest index was obtained in IW/CPE $0.8\left(\mathrm{I}_{1}\right)$ irrigation schedules and increased the grain yield 17.27 and $17.02 \%$ over IW/CPE1.2 $\left(\mathrm{I}_{3}\right)$.

\section{Consumptive use}

The consumptive use of water $(23.0$ and $23.8 \mathrm{~cm}$ ) was more under flat method (Table 3 ) followed by the $\mathrm{B}_{75-2}$, $\mathrm{B}_{75-3}, \mathrm{~B}_{90-2}, \mathrm{~B}_{90-3}$ and lowest value of consumptive use was recorded under $\mathrm{B}_{90-4}$ land configuration during both the year of study. The consumptive use of water directly related with moisture depletion and it was higher under flat method and lowest under bed $\mathrm{B}_{90-4}$ land 
configuration. During 2015-16 total consumptive use of water was more than 2014-15. The consumptive use of water directly related with moisture depletion and it was higher under flat method and lowest under $\mathrm{B}_{90-4}\left(\mathrm{~B}_{5}\right)$ land configuration. So, consumptive use of water was also in the order of moisture depletion. During first year total consumptive use of water was more than the second year mainly due to the differences in weather conditions, such as hot and dry wind and lesser number of rainy day.

Irrigation schedule of $4 \mathrm{~cm}$ irrigation IW: CPE 0.8. In contrast, the lowest consumptive use of water (17.2 and $17.6 \mathrm{~cm}$ ) was under the irrigation schedule of IW: CPE1.2 due to combination of higher surface evaporation and more transpiration so that moisture stresses condition occurs. Ahmad (2002) also observed similar results in wheat on a sandy loam soil under semiarid conditions. While, Maurya and Singh (2008) observed maximum profile water depletion and $\mathrm{ET}_{\mathrm{a}}$ of wheat in the wetter moisture regime of IW: CPE of 1.2 than the lower ones. The consumptive use of water showed an increasing trend with increase in irrigation water during both the years. The highest consumptive use was recorded with irrigation schedule of IW: CPE $0.8\left(\mathrm{I}_{1}\right)$. This was mainly due to fact that the greater loss of applied water through evapotranspiration because of more availability of water resulted into better foliage and ultimately better plant growth. As a result of this was greater absorption of moisture by crop favoured by highest water use at wettest regime. In contrast, the lowest consumptive use of water $(17.6$ and $17.2 \mathrm{~cm})$ was under the irrigation schedule of IW: CPE $1.2\left(\mathrm{I}_{3}\right)$ due to combination of lower surface evaporation and reduced transpiration under less moisture availability.

\section{Water-use efficiency}

It is evident from the data (Table 3) that highest water use efficiency was recorded $\left(2.53\right.$ and $\left.2.51 \mathrm{~kg} \mathrm{~m}^{-3}\right)$ under $\mathrm{B}_{90-4}\left(\mathrm{~B}_{5}\right)$ land configuration over flat planting method $\left(\mathrm{B}_{6}\right)$ during both the year of study. Treatment $\mathrm{B}_{90-4}\left(\mathrm{~B}_{5}\right)$ increased 39.01and $39.44 \%$ over flat method during 201415 and 2015-16, respectively. This might be due to higher grain yield obtained under $B_{90-4}\left(B_{5}\right)$ land configuration with lesser amount of water used. Declined water-use efficiency (WUE) under flat method with IW: CPE $0.8\left(\mathrm{I}_{1}\right)$ might be due to fact that grain yield did not increase proportionately to that of consumptive use under this treatment. Table 3 clearly indicates that water-use efficiency decreased with increase in levels of irrigation during both the years. Maximum value of WUE, 2.19 and $2.18 \mathrm{~kg} \mathrm{~m}^{-3}$, were noted in IW: CPE $1.2\left(\mathrm{I}_{3}\right)$ during first and second years respectively. It increased 15.2 and $16.0 \%$ over IW: CPE $0.8\left(\mathrm{I}_{1}\right)$ during first and second year, respectively. However minimum water-use efficiency was under IW: CPE $0.8\left(\mathrm{I}_{1}\right)$ during both the years. Decrease in WUE with IW: CPE $0.8\left(\mathrm{I}_{1}\right)$ based on the fact that the proportionate increase in grain yield was less than increase in the consumptive use of water

Table.1 Effect of land configuration and irrigation schedules on yield attributes

\begin{tabular}{|c|c|c|c|c|c|c|c|c|}
\hline \multirow[t]{2}{*}{ Treatment } & \multicolumn{2}{|c|}{ Spike length $(\mathbf{c m})$} & \multicolumn{2}{|c|}{$\begin{array}{l}\text { No. of Spikelet's } \\
\text { spike }^{-1}\end{array}$} & \multicolumn{2}{|c|}{ No. of grains spike ${ }^{-1}$} & \multicolumn{2}{|c|}{ Test weight (g) } \\
\hline & 2014-15 & 2015-16 & 2014-15 & 2015-16 & 2014-15 & 2015-16 & 2014-15 & 2015-16 \\
\hline \multicolumn{9}{|l|}{ Land configuration } \\
\hline $75 \mathrm{~cm}$ bed, 2 rows & 12.3 & 12.5 & 20.8 & 22.1 & 54.7 & 56.8 & 43.46 & 43.80 \\
\hline $75 \mathrm{~cm}$ bed, 3 rows & 11.3 & 11.5 & 19.3 & 20.3 & 51.0 & 53.0 & 41.40 & 41.67 \\
\hline $90 \mathrm{~cm}$ bed, 2 rows & 12.1 & 12.3 & 24.2 & 25.2 & 55.9 & 58.6 & 44.15 & 44.67 \\
\hline $90 \mathrm{~cm}$ bed, 3 rows & 11.0 & 11.3 & 23.9 & 25.2 & 55.4 & 57.8 & 44.01 & 44.41 \\
\hline $90 \mathrm{~cm}$ bed, 4 rows & 11.0 & 11.2 & 21.3 & 22.3 & 52.8 & 54.4 & 43.51 & 43.87 \\
\hline Flat planting & 10.1 & 10.3 & 18.8 & 19.8 & 50.0 & 52.3 & 42.74 & 42.95 \\
\hline C.D. $(P=0.05)$ & 0.18 & 0.22 & 1.00 & 0.63 & 1.11 & 1.41 & 0.45 & 0.46 \\
\hline \multicolumn{9}{|l|}{ Irrigation schedule } \\
\hline $4 \mathrm{~cm}$ irrigation at IW/CPE $0.8\left(\mathrm{I}_{1}\right)$ & 12.1 & 12.2 & 22.7 & 24.1 & 55.0 & 57.7 & 44.17 & 44.58 \\
\hline $5 \mathrm{~cm}$ irrigation at IW/CPE $1.0\left(\mathrm{I}_{2}\right)$ & 11.4 & 11.9 & 21.6 & 22.6 & 53.0 & 55.4 & 43.72 & 43.23 \\
\hline $6 \mathrm{~cm}$ irrigation at IW/CPE $1.2\left(\mathrm{I}_{3}\right)$ & 10.5 & 10.4 & 19.4 & 20.4 & 46.8 & 47.9 & 40.75 & 40.87 \\
\hline C.D. $(P=0.05)$ & 0.14 & 0.14 & 0.36 & 0.32 & 0.57 & 0.58 & 0.29 & 0.34 \\
\hline
\end{tabular}


Table.2 Effect of different treatments on grain, straw, biological yield ( $\left.\mathrm{qha}^{-1}\right)$ and harvest index (\%)

\begin{tabular}{|c|c|c|c|c|c|c|c|c|}
\hline \multirow[t]{2}{*}{ Treatment } & \multicolumn{2}{|c|}{ Grain yield } & \multicolumn{2}{|c|}{ Straw yield } & \multicolumn{2}{|c|}{ Biological yield } & \multicolumn{2}{|c|}{ Harvest index } \\
\hline & 2014-15 & 2015-16 & 2014-15 & 2015-16 & $2014-15$ & 2015-16 & 2014-15 & $2015-16$ \\
\hline \multicolumn{9}{|l|}{ Land configuration } \\
\hline $75 \mathrm{~cm}$ bed, 2 rows & 39.33 & 40.18 & 55.33 & 56.42 & 39.33 & 40.18 & 55.33 & 56.42 \\
\hline $75 \mathrm{~cm}$ bed, 3 rows & 40.28 & 41.39 & 56.47 & 57.20 & 40.28 & 41.39 & 56.47 & 57.20 \\
\hline $90 \mathrm{~cm}$ bed, 2 rows & 37.80 & 38.57 & 54.63 & 55.36 & 37.80 & 38.57 & 54.63 & 55.36 \\
\hline $90 \mathrm{~cm}$ bed, 3 rows & 43.06 & 44.12 & 57.79 & 58.33 & 43.06 & 44.12 & 57.79 & 58.33 \\
\hline $90 \mathrm{~cm}$ bed, 4 rows & 46.52 & 47.63 & 60.57 & 61.55 & 46.52 & 47.63 & 60.57 & 61.55 \\
\hline Flat planting & 41.92 & 42.52 & 56.59 & 57.35 & 41.92 & 42.52 & 56.59 & 57.35 \\
\hline C.D. $(P=0.05)$ & 1.79 & 1.70 & 2.34 & 2.50 & 1.79 & 1.70 & 2.34 & 2.50 \\
\hline \multicolumn{9}{|l|}{ Irrigation schedule } \\
\hline $4 \mathrm{~cm}$ irrigation at IW/CPE $0.8\left(\mathrm{I}_{1}\right)$ & 44.01 & 44.88 & 59.00 & 59.94 & 44.01 & 44.88 & 59.00 & 59.94 \\
\hline $5 \mathrm{~cm}$ irrigation at IW/CPE $1.0\left(\mathrm{I}_{2}\right)$ & 42.92 & 43.97 & 58.56 & 59.47 & 42.92 & 43.97 & 58.56 & 59.47 \\
\hline $6 \mathrm{~cm}$ irrigation at IW/CPE $1.2\left(\mathrm{I}_{3}\right)$ & 37.53 & 38.35 & 53.14 & 53.82 & 37.53 & 38.35 & 53.14 & 53.82 \\
\hline C.D. $(P=0.05)$ & 0.51 & 0.53 & 0.83 & 0.86 & 0.51 & 0.53 & 0.83 & 0.86 \\
\hline
\end{tabular}

Table.3 Effect of land configuration and irrigation schedule on water applied, consumptive use and productivity

\begin{tabular}{|c|c|c|c|c|c|c|c|c|c|}
\hline \multirow{2}{*}{\multicolumn{2}{|c|}{ Treatment }} & \multicolumn{2}{|c|}{$\begin{array}{c}\text { Total water applied } \\
(\mathbf{c m})\end{array}$} & \multicolumn{2}{|c|}{ Consumptive use (cm) } & \multicolumn{2}{|c|}{$\begin{array}{l}\text { Water use efficiency } \\
\qquad\left(\mathrm{kg} \mathrm{m}^{-3}\right)\end{array}$} & \multicolumn{2}{|c|}{$\begin{array}{c}\text { Water Productivity } \\
\left(\mathrm{kg} / \mathrm{m}^{-3}\right)\end{array}$} \\
\hline & & 2014-15 & 2015-16 & 2014-15 & 2015-16 & 2014-15 & 2015-16 & 2014-15 & 2015-16 \\
\hline \multicolumn{10}{|l|}{ Land configuration } \\
\hline $75 \mathrm{~cm}$ bed, 2 rows & $\left(\mathrm{B}_{75-2}\right)$ & 19 & 16 & 22.2 & 22.8 & 1.77 & 1.76 & 2.07 & 2.51 \\
\hline $75 \mathrm{~cm}$ bed, 3 rows & $\left(\mathrm{B}_{75-3}\right)$ & 19 & 16 & 21.6 & 22.1 & 1.86 & 1.87 & 2.12 & 2.59 \\
\hline $90 \mathrm{~cm}$ bed, 2 rows & $\left(\mathrm{B}_{9-2}\right)$ & 19 & 16 & 19.3 & 20.0 & 1.96 & 1.93 & 1.99 & 2.41 \\
\hline $90 \mathrm{~cm}$ bed, 3 rows & $\left(\mathrm{B}_{90-3}\right)$ & 19 & 16 & 19.2 & 19.7 & 2.24 & 2.24 & 2.27 & 2.76 \\
\hline $90 \mathrm{~cm}$ bed, 4 rows & $\left(\mathrm{B}_{90-4}\right)$ & 19 & 16 & 18.4 & 19.0 & 2.53 & 2.51 & 2.45 & 2.98 \\
\hline Flat planting & $\left(B_{6}\right)$ & 19 & 16 & 23.0 & 23.6 & 1.82 & 1.80 & 2.21 & 2.66 \\
\hline \multicolumn{10}{|l|}{ Irrigation schedule } \\
\hline $4 \mathrm{~cm}$ irrigation at IW & E $0.8\left(I_{1}\right)$ & 21 & 16 & 23.2 & 23.8 & 1.90 & 1.88 & 2.10 & 2.81 \\
\hline $5 \mathrm{~cm}$ irrigation at IW & E $1.0\left(\mathrm{I}_{2}\right)$ & 20 & 15 & 21.5 & 22.1 & 1.99 & 1.99 & 2.15 & 2.93 \\
\hline $6 \mathrm{~cm}$ irrigation at $\mathrm{IW}$ & E $1.2\left(\mathrm{I}_{3}\right)$ & 17 & 18 & 17.2 & 17.6 & 2.19 & 2.18 & 2.21 & 2.13 \\
\hline
\end{tabular}

Note: Total water used by the crop includes applied irrigation and effective rainfall \& consumptive use by the crop includes total soil moisture depletion $(\mathrm{cm})$ and soil moisture contributes.

Table.4 Effect of crop establishment method and irrigation schedule on profitability of wheat crop

\begin{tabular}{|c|c|c|c|c|c|c|c|c|c|}
\hline \multirow{2}{*}{\multicolumn{2}{|c|}{ Treatment }} & \multicolumn{2}{|c|}{$\begin{array}{l}\text { Cost of cultivation } \\
\left(\mathrm{Rs} \mathrm{ha}^{-1}\right)\end{array}$} & \multicolumn{2}{|c|}{$\begin{array}{c}\text { Gross income } \\
\left(\mathrm{Rs} \mathrm{ha}^{-1}\right)\end{array}$} & \multicolumn{2}{|c|}{$\begin{array}{l}\text { Net returns } \\
\left(\text { Rs ha }^{-1}\right)\end{array}$} & \multicolumn{2}{|c|}{ Benefit :cost ratio } \\
\hline & & 2014-15 & 2015-16 & 2014-15 & 2015-16 & 2014-15 & 2015-16 & 2014-15 & $2015-16$ \\
\hline \multicolumn{10}{|l|}{ Land configuration } \\
\hline $75 \mathrm{~cm}$ bed, 2 rows & $\left(B_{75-2}\right)$ & 28520 & 29343 & 73628 & 78008 & 45108 & 48065 & 1.58 & 1.64 \\
\hline $75 \mathrm{~cm}$ bed, 3 rows & $\left(\mathrm{B}_{75-3}\right)$ & 28520 & 29343 & 75347 & 80036 & 46827 & 50093 & 1.64 & 1.71 \\
\hline $90 \mathrm{~cm}$ bed, 2 rows & $\left(\mathrm{B}_{9-2}\right)$ & 27820 & 28643 & 71199 & 75303 & 43379 & 46060 & 1.56 & 1.61 \\
\hline $90 \mathrm{~cm}$ bed, 3 rows & $\left(\mathrm{B}_{90-3}\right)$ & 27820 & 28643 & 79774 & 84390 & 51954 & 55147 & 1.87 & 1.93 \\
\hline $90 \mathrm{~cm}$ bed, 4 rows & $\left(\mathrm{B}_{90-4}\right)$ & 27820 & 28643 & 85625 & 90606 & 57805 & 61363 & 2.08 & 2.14 \\
\hline Flat planting & $\left(\mathrm{B}_{6}\right)$ & 28740 & 29630 & 77590 & 81727 & 49950 & 52764 & 1.74 & 1.78 \\
\hline \multicolumn{10}{|l|}{ Irrigation schedule } \\
\hline \multicolumn{2}{|c|}{$4 \mathrm{~cm}$ irrigation at IW/CPE $0.8\left(\mathrm{I}_{1}\right)$} & 28490 & 29380 & 81485 & 86055 & 53762 & 57059 & 1.89 & 1.94 \\
\hline \multicolumn{2}{|c|}{$5 \mathrm{~cm}$ irrigation at IW/CPE $1.0\left(\mathrm{I}_{2}\right)$} & 28206 & 28930 & 79775 & 84571 & 51752 & 55075 & 1.83 & 1.90 \\
\hline \multicolumn{2}{|c|}{$6 \mathrm{~cm}$ irrigation at IW/CPE $1.2\left(\mathrm{I}_{3}\right)$} & 27923 & 28813 & 70331 & 74445 & 42008 & 44649 & 1.50 & 1.55 \\
\hline
\end{tabular}




\section{Water productivity}

The maximum water productivity was registered $(2.45$ and $2.98 \mathrm{~kg} \mathrm{~m}^{-3}$ ) under $\mathrm{B}_{90-4}$ land configuration, followed by $\mathrm{B}_{90-3}>$ flat, $\mathrm{B}_{75-3}>\mathrm{B}_{75-2}>\mathrm{B}_{90-2}$, treatments during both the years. Higher water productivity $\left(2.21 \mathrm{~kg} \mathrm{~m}^{-3}\right)$ was affected by irrigation schedule of IW: CPE $1.2\left(\mathrm{I}_{3}\right)$ during 2014-15, but during 2015-16 higher water productivity $\left(2.93 \mathrm{~kg} \mathrm{~m}^{-3}\right)$ was observed under IW/CPE $1.0\left(\mathrm{I}_{2}\right)$. Increase in water productivity (Table 3) with IW: CPE $1.2\left(\mathrm{I}_{3}\right)$ based on the fact that the proportionate increase in grain yield with lesser number of irrigations during experimentation. The results corroborate with the similar findings of (Kumar 2010; Singh et al., 2015). In general, water productivity affected by irrigation schedules the higher water productivity observed with IW: CPE $0.8\left(\mathrm{I}_{1}\right)$ during both the year of study. However minimum water productivity was observed in IW: CPE $1.2\left(\mathrm{I}_{3}\right)$. Decrease in water productivity with IW: CPE 1.2 $\left(\mathrm{I}_{3}\right)$.

\section{Economics}

Gross income, net income, benefit: cost ratio was influenced by crop establishment methods and irrigation management practices during both the year (Table 4). The maximum gross income ( 85625 and 90606), net income (57805 and Rs 61363) and benefit cost ratio (2.08 and 2.14) were recorded with treatment $\mathrm{B}_{90-4}$, which were higher than other land configuration method. Whereas the minimum net return and benefit: cost ratio was recorded in flat planting $\left(\mathrm{B}_{6}\right)$.Higher net return in $\mathrm{B}_{90-4}$ than $\mathrm{B}_{6}$ has been reported by Idnani and Kumar (2013). Among the irrigation practices, the maximum gross income ( 81485 and $86055 \mathrm{ha}^{-1}$ ), and net income ( 53762 and Rs. $57059 \mathrm{ha}^{-1}$ ) and benefit: cost ratio (1.89 and 1.94) was recorded with IW/CPE $0.8\left(\mathrm{I}_{1}\right)$ treatment followed by IW/CPE $1.0\left(\mathrm{I}_{2}\right)$ in both the years. This might be due to higher productivity of the wheat crop. These results are in conformity with the findings of Kumar et al., (2013); Naresh et al., (2013a).

\section{Conclusion}

From the present investigation, it could be concluded that growth, and yield of wheat affects significantly with the land configuration and irrigation schedule. Among the different crop establishment method land configuration $\mathrm{B}_{90-4}$ performed higher grain yield 46.52 and $47.63 \mathrm{q} \mathrm{ha}^{-1}$, gross return of Rs.85625 and Rs. $90606 \mathrm{ha}^{-1}$ and net return of Rs. 57805 and Rs. 61363 with B: C ratio 2.08 and 2.14 during experimentation.
The irrigation schedule performed consistently better results in IW/CPE $0.8 \quad\left(\mathrm{I}_{1}\right)$ than other irrigation schedule as indicated by grain yield 44.01 and 44.88 , gross returns Rs. 81515 and $86055 \mathrm{ha}^{-1}$, net return Rs. 53762 and Rs. 57059 ha $^{-1}$ and B: C ratio1.89 and 1.94, respectively. However, yield advantage in furrow irrigated raised bed planting system over flat planting system. Farmers can easily respond to this technology if efforts are diverted to demonstrate yield differences between flat and bed planting systems either by modifying land configuration or crop rows planted on the top of the beds or selection of suitable irrigation schedule.

\section{Acknowledgement}

This study has been executed at the Crop research centre of Sardar Vallabhbhai Patel University of Agriculture and Technology, Meerut, Uttar Pradesh, India under the Department of Agronomy between 2014-15 and 201516. I would like to thank the Department of Agronomy for offering me the necessary facilities during this period. Moreover, we would like to express our great respect for the editors and anonymous reviewers to improve the manuscript quality.

\section{References}

Ahmad, A. 2002.Effect of irrigation scheduling on the performance of wheat genotypes in vertisols. M.Sc. (Agri.) Thesis, University of Agricultural Sciences, Dharwad.

Amanullah, M., Zakirullah, S, K, Khalil. 2009. Timing and Rate of Phosphorus Application influence wheat Phenology, Yield and Profitability in Northwest Pakistan. Int. J Plant Prod., 4 (4): 281292

Beecher H G, Thompson J A, Dunn B W, Mathews S K. 2005. Successful permanent raised beds in the irrigated farming systems of the Murrumbidgee and Murray valleys of New South Wales, Australia. In: Roth C H, Fischer R A, Meisner C A. Evaluation and Performance of Permanent Raised Bed Cropping Systems in Asia, Australia and Mexico. Proceedings of a Workshop Held in Griffith, NSW, Australia, 1-3 March 2005. ACIAR Proceedings No. 121: 129-142.

Bhahma, Ranjita.,Janawade, A. D., Palled, Y. B. 2007. Water use studies in durum wheat as influenced by irrigation schedules, mulch and antitranspirant application in black soils of northern transitional 
zone of Karnataka. Karnataka J. Agri. Sci., 20(1):120-122.

Idnani, L.K. and Kumar, Ashok. 2013. Performance of wheat (Triticum aestivum L.) under different irrigation schedules and sowing methods. Indian $J$. Agri. Sci., 83 (1): 37-40.

Jat, L. N. and Singh, S. M. 2003.Varietal suitability, productivity and profitability of wheat (Triticum species) intercrops and relay cropping under furrowirrigated raised bed system. Indian J. Agri. Sci., 73(4): 187-190.

Kumar, Ashok, Sharma,K. D., Yadav, Ashok. 2010. Enhancing yield and water productivity of wheat (Triticum aestivum) through furrow irrigated raised bed system in the Indo-Gangetic Plains of India. Indian J. Agri. Sci., 80 (3):198-202.

Kumar, M., Das, A., Ramkrushna, G. I., Patel, D. P., Munda, G. C., Naropongla and Buragohain, J. 2013. Effect of nutrient sources and transplanting date on aromatic rice (Oryza sativa) under mid hills of north eastern India. Indian J. Agron., 58 (3): 322-6.

Maurya, R. K., Singh, G. R. 2008. Effect of crop establishment methods and irrigation schedules on economics of wheat (Triticum aestivum) production, moisture depletion pattern, consumptive use and crop water-use efficiency. Indian J. Agri. Sci., 78 (10):830-833.

Naresh, R. K., Gupta, R. K., Kumar, A., Singh, B., Prakash, S., Kumar, S. and Rathi, R. C. 2011. Direct-seeding and reduced-tillage options in the rice-wheat system of the Western Indo-Gangetic Plains. Int. J. Agric. Sci., 7(1): 197-208.
Naresh, R.K., Singh, S.P. and Kumar, Vineet. 2013a. Crop establishment, tillage and water management technologies on crop and water productivity in ricewheat cropping system of North West India. Int. J. Sci. Life Sci. Biotech. Pharma Res., 2 (4):1-12.

Prihar, S. S. and Khepar, S. D. 1997. Resource management for sustainable intensive agriculturewater. Proc. Third Agrilcultural Science Congress, National Academy of Agricultural Sciences, Ludhiana, pp 91-101.

Prihar, S.S. and Sandhu, B.S. 1987. Irrigation of Field Crops - Principles and Practices. Indian Council of Agricultural Research (ICAR), New Delhi.

Prihar, S. S., Gajri, P. R. and Narang, R. S. 1974. Scheduling irrigation to wheat using open pan evaporation. Indian J. Agri. Sci., 44: 567-71.

Saharawat, Y. S., Singh, B., Malik, R. K., Ladha, J. K., Gathala, M. K., Jat, M. L. and Kumar, V. 2010. Evaluation of alternative tillage and crop establishment methods in a rice-wheat rotation in North Western IGP. Field Crops Res, 116: 260-267.

Singh, Karmal, Dhindwal, A.S., Dhaka, A.K., Sewhag, Meena and Pannu, R.K. 2015.Water use pattern and productivity in bed planted wheat (Triticum aestivum L.) under varying moisture-regimes in shallow water table conditions. Indian J. Agri. Sci., 85(8): 1080-1084.

Thind, H.S, Buttar, G.S. and Aujla, M.S. 2010. Yield and water use efficiency of wheat and cotton under alternate furrow and check basin irrigation with canal and tube well water in Punjab, India. Irrig. Sci., 28(6): 489-96.

\section{How to cite this article:}

Vipin Kumar Sagar, R.K. Naresh, Vivak Kumar, Satendra Kumar, Saurabh Tyagi, Vineet Kumar, Sunil Kumar, Nihal Chandra Mahajan, Arun Kumar, Vikrant Singh, S.P. Singh and R.C. Rathi. 2017. Crop Establishment Method and Irrigation Schedule Effect on Water Productivity, Economics and Yield of Wheat (Triticum aestiuvm L). Int.J.Curr.Res.Aca.Rev. 5(5), 70-77. doi: https://doi.org/10.20546/ijcrar.2017.505.009 